\title{
Churg-Strauss Syndrome: a syndrome described on clinical observation and autopsy findings
}

\author{
Fernando P. F. de Campos ${ }^{a}$, Stephen A. Geller
}

Campos FPF, Geller SA. Churg-Strauss Syndrome: a syndrome described on clinical observation and autopsy findings. [editorial]. Autopsy Case Rep [Internet]. 2013;3(2):1-4. http://dx.doi.org/10.4322/acr.2013.011

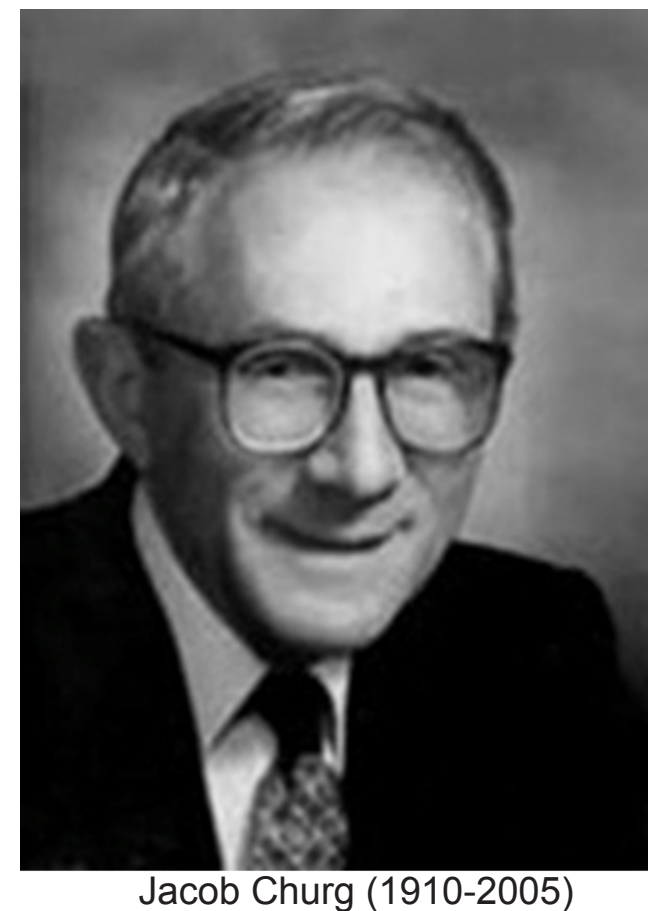

Dr. Jacob Churg (1910-2005) was born in Dolhinow, a Belarusian city that later became a part of Poland and in 1939 was ceded to Russia during the partition of Poland by Russia and Germany. Churg's father, Wolf, was a physician, and his mother, Gita, a dentist. Jacob recalled reading his father's medical books and pestering him with many questions. He graduated with a medical degree from the University of Wilno (Poland) in 1933 and started working at the Department of Internal Medicine. $\mathrm{He}$ realized that he was less confident dealing with patients than with "tissues." In 1936, at the same university, he began his studies in experimental pathology.

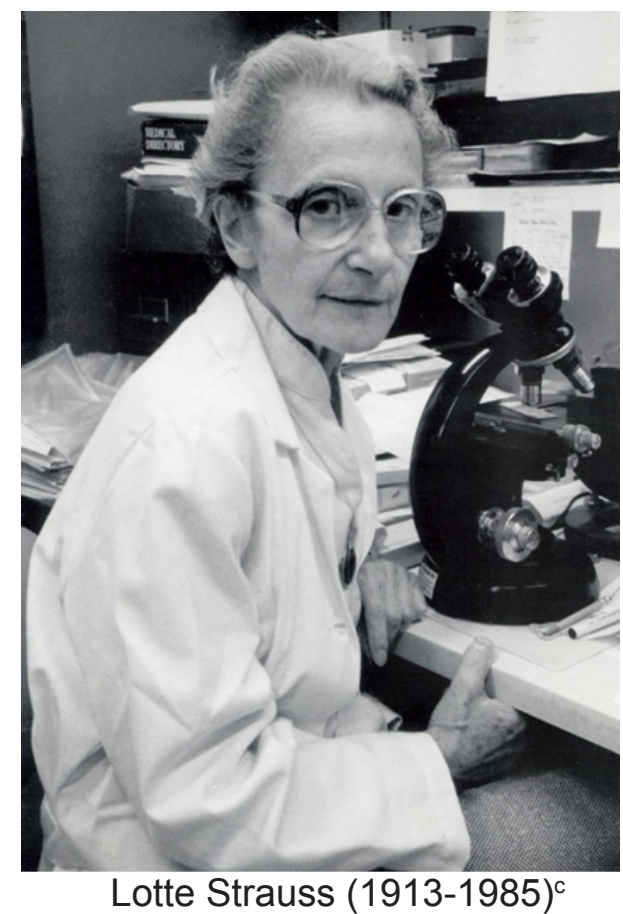

When he arrived in the United States, his uncle, Dr. Louis Chargin, chief physician at the skin clinic at Mount Sinai Hospital, New York, invited him to work as a dermatologist. After some attempts with that clinical practice, he decided to work in the bacteriological laboratory conducting research in the toxicity of various sulfa preparations.

In 1942, he joined the Mount Sinai Department of Pathology whose director was Dr. Paul Klemperer, one of the greatest pathologists of the early twentieth century, and also studied under Dr. Sadao Otani, the legendary surgical pathologist. This is where Churg began his studies of renal diseases with autopsy material, and subsequently

\footnotetext{
a Department of Internal Medicine - Hospital Universitário - Universidade de São Paulo, São Paulo/SP - Brazil.

${ }^{b}$ Department of Pathology and Laboratory Medicine - David Geffen School of Medicine, UCLA, Los Angeles/CA - USA.

${ }^{c}$ Photo courtesy of Dr. Stephen A Geller.
}

Copyright $\odot 2013$ Autopsy and Case Reports - This is an Open Access article distributed of terms of the Creative Commons Attribution NonCommercial License (http://creativecommons.org/licenses/by/3.0/) which permits unrestricted non-commercial use, distribution, and reproduction in any médium provided article is properly cited. 
became one of the pioneers in the interpretation of kidney biopsies. He developed many new techniques to enhance the examination and interpretation of renal histology, including electron microscopy when it became available. His studies on diseases that were poorly understood at the time established the modern standards for the comprehension of many kidney diseases, including lupus nephritis, focal glomerulosclerosis, diabetes mellitus, hemolytic uremic syndrome, crescentic glomerulonephritis, and amyloidosis. In addition, he studied pulmonary and pleural diseases (concentrating on those that were asbestos-related, including mesothelioma and lung cancer), and was an authority on vascular diseases.

He was at Mount Sinai Hospital most of his career, while also serving as Chief of Pathology at Barnert Memorial Hospital, a community hospital in New Jersey. After military service during World War II, he commenced his long friendship and collaboration with Lotte Strauss at Mount Sinai Hospital.

Dr. Lotte Strauss (1913-1985) was born in Nuremberg, Germany. She began her medical studies in Germany, but was forced to complete them in Siena, Italy, in 1937, where she first demonstrated interest in laboratory medicine. She moved to the United States in 1938, working at Beth Israel Hospital, New York, as a research assistant in bacteriology. She became committed to pathology after studying with Dr. Sydney Farber (1903-1973), a well-known pediatric pathologist, at Children's Hospital in Boston. He is remembered for Farber's disease and particularly for studies in childhood leukemia, which led to effective chemotherapy. Boston's Sydney Farber Institute is named after him.

In 1941, Straus also came to Mount Sinai Hospital, where Klemperer encouraged her to concentrate on pediatric pathology. Subsequently, she became recognized as one of the most important founders of the specialty. She was a pioneer of perinatal pathology and helped establish the Society for Pediatric Pathology. Her special interests included studies on the ultrastructure of the placenta in various fetal diseases, intrauterine infections, and vascular diseases.

In 1953, a pediatric pathology service was established at Mount Sinai and she was its director for more than 30 years until her death. In 1966, she became one of the founding faculty at the Mount
Sinai School of Medicine with the rank of professor. Among her honors was the appointment as Special Consultant in Perinatal Pathology to the National Institute of Health.

\section{THE SYNDROME}

From 1866, when Dr. Adolf Kussmaul and Dr. Rudolf Maier described what today is called polyarteritis nodosa (PAN), all forms of vasculitis, independent of the size or type of vessel involved, tended to be consider as forms of PAN.

In 1923, Dr. William Ophuls in San Francisco, described lesions characterized by granulomas and eosinophilic infiltrates of the respiratory tract, arteritis, venulitis and nephritis. Although he reported as a form of PAN he found it odd because of he presence of granulomas and eosinophilic infiltrates in numerous organs and especially by the complete absence of aneurysms, which he had expected to find in periarteritis. In 1924 Sadao Otani described a case of periarteritis nodosa accompanied by asthma and eosinophilia, but did not did not view his case as nosologically distinct.

In 1931, Dr. Heinz Klinger (Berlin), reported two cases clinically characterized by arthritis, nephritis and chronic sinusitis. The autopsy of one of these cases showed necrotizing lesions into the base of the skull, tracheal ulcerations, destruction of nasal septum and glomerulonephritis. The histology showed vasculitis and granulomas. $\mathrm{He}$ called the disease as "granulomatosis with polyangiitis" interpreting as a different form of PAN. In two publications dating from 1936 and 1939, Dr. Friedrich Wegener (Breslau - Germany) better characterized this form of necrotizing granulomatous vasculitis involving the upper respiratory tract and renal vasculitis, as a distinct clinical and pathological entity. This disease, which until recently, was named Wegener granulomatosis, is now called "granulomatosis with polyangiitis". In 1940, Davson et al., and Zeek et al., concomitantly described a microscopic form of PAN affecting small arteries, arterioles, capillaries and venules that cause necrotizing glomerulonephritis, today called microscopic polyangiitis.

Churg later had a patient at Barnert Memorial Hospital who presented with lymphadenopathy and peripheral eosinophilia, and had a history of asthma. Lymph node biopsy showed early granulomas and 
eosinophilic infiltration, previously unknown to Churg. Among the considerations at that time was Hodgkin lymphoma, but the lymph nodes regressed and the patient died of cerebral hemorrhage, proven, at autopsy, to be due to central nervous system vasculitis. In addition, other tissues showed granulomas and eosinophilia.

Concomitantly, Strauss had a similar case at Mount Sinai Hospital. Reviewing the literature together, they found similar cases previously reported. Identifying similar cases in the Mount Sinai Hospital archives and others reported in the literature, Churg and Strauss collected 13 cases. All of them presented with asthma, fever, hypereosinophilia, and, to varying degrees, symptoms of cardiac failure, renal damage, and peripheral neuropathy resulting from vascular insufficiency in various organs. The syndrome they described showed widespread inflammatory cell infiltration in the walls of vessels and in the extravascular collagen tissue, including necrosis with eosinophilic exudate, severe "fibrinoid" necrosis, and proliferating granulomas comprised of epithelioid and giant cells. They designated this change, and the accompanying syndrome, as "allergic granulomatosis," suggesting that the granulomas indicated a variant of polyarteritis nodosa.

Three years later, in 1954, Churg and Gabriel C Godman, a pathologist at Columbia University, concluded that Churg-Strauss syndrome, Wegener granulomatosis, and microscopic polyangiitis were related types of vasculitis distinct from classic polyarteritis nodosa. All three typically affected small arteries, arterioles, capillaries, venules and veins, and might be associated with glomerulonephritis. This conclusion has greatly been strengthened by the observation that all three typically do not show a deposition of immunoglobulins in tissue (hence are labeled pauci-immune) and usually typically demonstrates circulating anti-neutrophil cytoplasmic antibodies (ANCA). Tissue samples are no longer required for diagnosis. Indeed, although eosinophilia is almost always seen, it is thought that the classic features of vasculitis and granulomatous inflammation are seen in only a minority of cases. Early cases may have rhinitis and asthma, with tissue eosinophilia, prior to the development of vasculitis. The cases without vasculitis are often highly responsive to steroid therapy, whereas more advanced cases may require cytotoxic and/or immunosuppressive treatment.

In this issue, a Churg-Strauss syndrome case is presented, which closely follows the clinical description by Dr. Jacob Churg and Dr. Lotte Strauss.
The autopsy findings dispel any doubt regarding the diagnosis. Probably at the time of their first description, Churg and Strauss could not establish the association between the syndrome and the high occurrence of thromboembolic events, as they also occur with others ANCA-related vasculitides

We take this opportunity to not only remember the syndrome but also the researchers and scientists who first described it and contributed greatly to our medical knowledge.

\section{BIBLIOGRAPHY}

Churg J, Strauss L. Allergic granulomatosis, allergic angiitis, and periarteritis nodosa. Am J Pathol. 1951;27:277-301.

Davson J, Ball J, Platt R. The kidney in periarteritis nodosa. Q J Med. 1948;17:175-202.

Godman GC, Churg J. Wegener granulomatosis. Arch Pathol. 1954;58:533-53.

International Society of Nephrology - ISN. ISN Viveo Legacy Project. Dr. Jacob Churg interviewed by Roland Blantz, University of California at San Diego, LA, Jolla, California, May 22, 1997. International Society of Nephrology; 2009 [cited 2013 Jan 20]. Available from: http://cybernephrology.ualberta.ca/ISN/VLP/ Trans/Churg.htm

Icahn School of Medicine at Mount Sinai. Hall of Fame at the Lillian and Henry M. Stratton-Hans Popper Department of Pathology. New York: Mountain Sinai Hospital; 2013 [cited 2013 Feb 10]. Available from: http://icahn.mssm.edu/departments-and-institutes/ pathology/about-us/hall-of-fame

Hunter JAA, Holubar K. The man behind the eponym. Am J Dematopathol. 1986;8:358-9 [cited 2013 Jan 20]. Available from: http://journals.Iww.com/amjdermatopathology/Citation/1986/08000/ Dr_Jacob_Churg.15.aspx

Churg A. Dr. Andrew Churg - history of CSS. [place unknow]: Churg-Strauss Syndrome Association; c2013 [cited 2013 Mar 20]. Available from: http://www.cssassociation.org/research-reader/ items/dr-andrew-churg-history-of-css.html

Jacob Churg. Whonamedit?; 2013 [cited 2013 Jan 20]. Available from: http://www.whonamedit.com/doctor.cfm/2348.html

Lotte Strauss. Whonamedit?; 2013 [cited 2013 Jan 20]. Available from: http://www.whonamedit.com/doctor.cfm/2350.html

The Dr. Lotte Strauss prize. Int Pathol. 1985;26(3):1-2 [cited 2013 Mar 29]. Available from: https://docs.google.com/viewer?a=v\&p$\mathrm{id}=$ sites\&srcid=aWFwY2VudHJhbC5vcmd8bWFpbnxneDo0Zjl1 NWJkZmYyZDEzMWE4 
Jennette JC, Falk RJ, Bacon PA, et al. 2012 Revised International Chapel Hill Consensus Conference Nomenclature of Vasculitides. Arthritis Rheum. 2013;65:1-11. PMid: 23045170. http://dx.doi. org/10.1002/art.37715

Klinger H. Grenzformen der periarteriitis nodosa. Frankfurt Ztschr Pathol. 1931;42:455-80.

Kussmaul A, Maier R. Über eine bisher nicht beschriebene eigenthümliche Arterienerkrankung (Periarteritis nodosa), die mit Morbus Brightii und rapid fortschreitender allgemeiner Muskellähmung einhergeht. Deutsche Arch klin Med. 1866;1:484518.

Matteson EL. A history of early investigation in polyarteritis nodosa. Arthritis Care Res. 1999;12:294-302. http://dx.doi.org/10.1002/15290131(199908)12:4\%3C294::AID-ART8\%3E3.0.CO;2-6

Matteson EL. History of vasculitis: the life and work of Adolf Kussmaul. Clev Clin J Med. 2012;3 suppl 3:S54-6. http://dx.doi. org/10.3949/ccjm.79.s3.12

Matteson EL. Notes on the history of eponymic idiopathic vasculitis: the diseases of Henoch and Schönlein, Wegener, Churg and Strauss, Horton, Takayasu, Behçet, and Kawasaki. Arthritis
Care Res. 2000;13:237-45. http://dx.doi.org/10.1002/15290131(200008)13:4\%3C237::AID-ANR8\%3E3.0.CO;2-J

Matteson EL. Polyarteritis nodosa and microscopic polyangiitis. Translation of the original articles on classic polyarteritis nodosa by Adolf Kussmaul and Rudolf Maier and microscopic polyarteritis nodosa by Friedrich Wohlwill. Rochester: Mayo Clinic Press; 1988.

Ophüls W. Periarteritis acuta nodosa. Arch Intern Med.1923;32:87098. http://dx.doi.org/10.1001/archinte.1923.00110240063004

Otani S. Zur Frage nach dem Wesen der sogenannten Periarteriitis nodosa. Frankfurt Ztschr Pathol. 1924;30:208-28.

Wegener F. Über generalisierte, septische Gefässerkrankungen. Verhandl Deutsch Gesellsch Pathol. 1936;29:202-10.

Wegener F. Über eine eigenartriege rhinogene Granulomatose mit besonderer Bteiligung des Arteriensystems und er Nieren. Beitr Pathol. 1939;102:32-68.

Zeek PM, Smith CC, Weeter JC. Studies on periarteritis nodosa. III The differentiation between the vascular lesions of periarteritis nodosa and hypersensitivity. Am J Pathol. 1948;24:889-917. PMid:18874416 PMCid:1942737.

Correspondence: Fernando Peixoto Ferraz de Campos

Scientific Editor Autopsy and Case Reports

Assistant Physician of Internal Medicine Division

Hospital Universitário - Universidade de São Paulo, São Paulo/SP - Brazil

E-mail: ffcampos@usp.br 